www.czasopisma.marszalek.com.pl/pl/10-15804/npw

\author{
СвеТЛАНА ЧЕРВОННАЯ \\ Университет Николая Коперника в Торуни \\ ORCID ID: https://orcid.org/0000-0002-2839-8052
}

\title{
«Национальный лидер» («отец народа») в европейском и азиатском восприятии (на примере вождей национального движения крымских татар)
}

«Национальный лидер» («отец народа») в европейском и азиатском восприятии (на примере вождей национального движения крымских татар)

\section{Аннотация}

Сформировавшиеся в массовом сознании стереотипы европейского и азиатского лидера не соответствуют современной действительности. В условиях культурной глобализации происходит сближение, порою полное совмещение друг с другом идеальных моделей политического лидера, вождя, главы государства, «отца народа» как в теории, так и в исторической практике европейских и азиатских народов и стран. Тем не менее некоторые различия между мусульманским Востоком и христианской, подвергнутой сильной секуляризации Европой остаются. Содержание понятия «национальный лидер / национальный герой» в Европе имеет более сильную этническую составляющую. «Своим» его признает чаще всего определенная этническая группа, в то время как на Востоке лидер мыслится обычно в масштабе суперэтнической, межгосударственной общности. Там на роль лидера чаще может претендовать духовное лицо, что в европейской системе отделения церкви от государства и невмешательства духовенства в политику практически исключается. Крым занимает исключительное положение на границе западной 
и восточной цивилизаций, и на примерах деятельности трех выдающихся лидеров крымских татар разных исторических периодов - просветителя либеральных взглядов, идеолога пантюркизма Исмаила Гаспринского, Муфтия Таврического, вставшего на путь революционной борьбы с царизмом и большевизмом Нумана Челеби Джихана и «советского диссидента», возглавившего в 1991 году Курултай и Меджлис крымскотатарского народа Мустафы Джемилева - видно, как меняются модели политических лидеров, их методы, цели и идеалы, каковы корни их массовой популярности.

Ключевые слова: политический лидер, национальный герой, цивилизации Запада и Востока

\section{"National leader" ("father of the nation") in the European and Asian perception (on the example of the leaders of the national movement of the Crimean Tatars)}

\section{Abstract}

The stereotypical an "European" and an "Asian" leader, formed in the mass consciousness, does not correspond with contemporary reality. Under the phenomenon of cultural globalization, there is a merging or at times a complete integration of ideal models, including the political leader, chief, head of the state and a "Father of the Nation". These ideal models exist both in theory and in historical practices of the European and Asian peoples and lands. Nonetheless, some distinctions are manifested between the East, referred to as the Muslim Orient, and the West, known as the Christian, strongly secularized Europe. The meaning of the notion a national leader or a national hero in Europe has a stronger ethnic component. In the West, the leader is most often recognized as an "our own" by an ethnic group. Meanwhile, in the East the leader is conceived as a head and member of a superethnic, inter-state community. In the East, a spiritual person can qualify for the role of the leader. This is unlikely to occur in the European system, where the Church and State are separated and there is a non-intervention of the clergy into politics for a long time. The Crimea has an exceptional location on the borderline of the Eastern and Western civilizations. The examples of three prominent Crimean Tatar leaders of different historical time periods demonstrate how their methods, goals and ideals change and the reasons behind their mass popularity. The three leaders are: Ismail Gasprinsky, educator of a liberal views and Panturkizm's ideologue; Numan Chelebi Djikhan, the Tavria's Mufty, who chose the path of revolutionary rebellion against tsarism and bolshevism; Mustafa Djemilev, an "Soviet dissident", who became a head of Crimean Tatar people's Kurultai and Medjlis in 1991.

Keywords: Political leader, national hero, Western and Eastern civilizations 


\section{Выдвижение лидера на выборной, демократической основе и на пути узурпации власти: европейский и азиатский опыт}

Сопоставление европейской (доминирующей в массовом сознании, развиваемой средствами массовой информации и пропаганды) и азиатской интерпретации понятия «национальный лидер» («отец нации», «отец народа»), казалось бы на первый взгляд, должно привести к однозначным выводам, во всяком случае при рассмотрении этого понятия и явления в парадигме Нового и Новейшего времени. А именно: здесь, в цивилизованной Европе, политическим лидером государства-нации становится человек, пользующийся доверием и поддержкой большинства населения, и демократическая процедура его избрания и утверждения на высшем посту (к примеру, президента, премьер-министра, председателя или «генерального секретаря» правящей партии, главы Народного Фронта) прозрачна, подконтрольна (контролируется всем национальным сообеством) и обеспечивает не только легальный с юридической точки зрения, но и вполне легитимный в нравственном аспекте характер такого лидерства (власти). Там, в Азии, которую еще многие европейцы считают «дикой», лидером может стать узурпатор власти, террорист, кровавый диктатор, готовый к беззастенчивой агрессии по отношению к другим народам и странам и не щадящий собственный народ, который тем не менее не только безмолвно и покорно терпит диктаторский режим, беспрекословно ему подчиняется, но и демонстрирует свою поддержку, часто весьма громогласную и сильно окрашенную эмоционально (вплоть до массовой восторженной истерики, охватывающей толпу), причем не только на специально организованных властью митингах, демонстрациях, парадах, но и на стихийных сборищах. Такое различие, выявляемое, как я уже сказала, «на первый взгляд», может найти подтверждение во множестве фактов, и припомнить такие факты нетрудно из совсем недавней и более давней истории.

Европейская политическая модель «лидера нации-государства», в основе которой лежит демократическая выборная система - выражение воли большинства населения страны, особенно наглядно проявляется на примерах, в известном смысле «негативных» и даже 
драматических для личной судьбы того или иного европейского политического лидера, вполне достойно заслужившего доверие своего народа, но на каком-то крутом витке истории, в каких-то связанных с непреодолимыми трудностями обстоятельствах это доверие утратившего. Разочарование (даже малейшее, даже не вполне обоснованное и не совсем справедливое) во внешней, внутренней, экономической политике такого лидера, тень подозрения, павшая на его имя, часто приводят к отставке, переизбранию еще недавно казавшегося бесспорным национальным героем и политическим лидером человека, который, как это принято в европейской традиции, принимает такую ситуацию, сохраняя внутреннее достоинство и внешнее спокойствие, и вовсе не обнаруживает намерения уничтожить соперника, занимаюего его место в итоге демократических выборов, а уж тем более обрушить кары на свой народ, принявший якобы (или действительно) неправильное, неразумное решение, и залить кровью родную страну, не признавшую его в качестве лидера. Примерами такого рода изобилует новейшая история: великий Уинстон Черчилль, спасший Великобританию во Второй мировой войне, уходит в 1945 году с высокого поста Премьер-Министра; даже в полу-европейской России первый и последний Президент СССР Михаил Горбачев, которому советский народ обязан историческими успехами «перестройки», отказывается от своего поста (которым он весьма дорожил и за который всеми силами боролся), обнаружив, что власть уже реально ушла из его рук и Советский Союз распался, - уходит достойно, а не хватается за «ядерный чемоданчик» и не приводит в наступление против собственного народа вооруженные силы страны, главнокомандующим которых он до последнего времени остается; возглавивший освободительное движение «Саюдис» политический лидер Литвы, вернувшей свою независимость, Витаутас Ландсбергис без малейшего сопротивления уступает высокий пост Президента страны своему сопернику, победившему на президентских выборах 1993 года - Альгирдасу Бразаускасу, хотя тот имеет значительно меньшие заслуги, чем Ландсбергис, в возрождении независимости Литвы; нечто подобное происходит с Лехом Валенсой: подлинный национальный герой, возглавивший в 1980-х годах великую польскую «Солидарность» и избранный на первых демократических выборах в послевоенной Польше Президен- 
том возрожденной Речи Посполитой, перестает быть Президентом по итогам выборов 1992 года. Такова Европа. А в Азии уже потерявший всякую легитимность, ставший персоной «нон-грата»в глазах всего человеческого сообщества Башар Асад ${ }^{1}$, удушающий собственный народ газами и умерщвляющий сирийских детей запрещенным химическим оружием, с отчаянной, утроенной или удесятеренной благодаря российскому военному вмешательству, яростной силой борется за собственную власть, не собираясь подвергнуть ее испытанию на всеобщих, равных и свободных демократических выборах и окружает себя искусственно созданными группировками, демонстрирующими национальную поддержку этому псевдо-лидеру. В Азии на роль национального (и даже интернационального, общемусульманского) лидера может претендовать террорист, самозванец, подобный Усаме Бен Ладану, организовавшему величайшую американскую трагедию 11 сентября 2001 года и много других, больших и малых трагедий на всех континентах ${ }^{2}$, или подобный Абу Бакру, объявившему себя калифом Исламского государства ${ }^{3}$ В азиатских государствах власть (и не формальный трон императоров и королевских династий, а реальная политическая власть, воплощенная в президентских структурах или в руководстве правящих партий) еще передается по наследству от отца к сыну, как это имеет место, например, в Северной Корее и даже в культурно наиболее близком Европе Азербайджане. Такова, как многим кажется, Азия.

123 мая 2011 года имя Башара Асада было внесено «в черный список ЕС» (Цыганок, 2016, с. 357).

2 «... Феномен Бин Ладена нельзя объяснить Кораном, - пишет Ежи Здановский, - так же, как на основе Библии нельзя объяснить феномен ИРА [Ирландской Республиканской Армии]. Однако исламский воинствующий экстремизм - это реальность. Вероятно, его формированию способствовал государственный авторитаризм и наглость политических режимов, защищающих свои корпоративные интересы, но от рук воинствующих исламистов погибло много невинных людей. Это привело к отождествлению всего исламизма и даже всего ислама с терроризмом. Ислам оказался ,бинладенизованным’» (Zdanowski, 2013, с. 308).

3 Абу Бакр Аль-Багдади начал борьбу с «неверными» в Ираке в 2003 году, в 2010 году объявил себя халифом Исламского Государства, которое официально заявило о своем существовании 27 июня 2014 года. Прославился крайней жестокостью (Подробнее о нем см.: Laurent, 2015). 
Однако, столь явное различие в положении «национального лидера», фиксируемое на первый поверхностный взгляд, на самом деле, если вникнуть в ситуацию глубже, оказывается не столь очевидным. «Лже-лидерами», «псевдо-лидерами», к сожалению, изобилует также история (в частности, новейшая история) европейских стран, и немало монстров, узурпировавших власть в итоге государственных переворотов (Ленин, Сталин и далее) или даже обеспечивших свой приход к власти формально легитимными выборами (Гитлер), залили кровью и собственные, и соседние страны и создали режимы, проводившие внешнюю агрессию и внутренний государственный террор, более жестокий, чем в какой-либо азиатской стране. Саддаму Хусейну, попытавшемуся захватить Кувейт, и не снилось того, что позволял себе немецкий фюрер, совершавший нападения на Польшу, Францию, Югославию, Советский Союз; политические лидеры современного («азиатского») Ирана, еще только грозящие своими намерениями уничтожить Израиль, явно уступают в мере своей преступности арийским главарям «европейского» Третьего Рейха, совершившим чудовищный холокост. Ни одна столица азиатского государства не заслужила в XX веке столь позорной славы, как расположенная на европейской территории советская Москва, совершавшая (по воле своих лидеров, которыми одновременно или сменяя друг друга, оказывались такие государственные и военные деятели, как Ленин, Сталин, Молотов, Троцкий, Тухачевский, Жуков) кровавые военные походы в Польшу, Финляндию, Украину, в прибалтийские страны, в румынскую Бессарабию, в Восточную Пруссию, а уже в новые времена - при Хрущеве в Венгрию и при Брежневе в Афганистан.

Любопытно было бы сравнить политические фигуры двух национальных лидеров первой трети ХХ века - «азиата», Президента Турецкой Республики Кемаля Ататюрка и «европейца» Ленина, вождя Советской России. В их деятельности было немало аналогичного как по методам, так и по сути проводимых реформ внутри страны и во внешней, военной, политической стратегии; они пользовались популярностью в массах собственного народа («всенародное горе» при прощании с Лениным вполне сопоставимо с трауром в Турции после смерти Кемаля Ататюрка), а личные контакты между ними при жизни (о дружбе в такой ситуации говорить не приходится, но Ле- 
нин очень дорожил связями с Ататюрком, посылал ему письма и телеграммы с разъяснением своей политики и намерений, Турция не случайно оказалась первым в мире государством, официально признавшим Советскую Россию, а затем и Советский Союз) еще более облегчают и оправдывают возможность такого сопоставления. Да, в чем-то они были похожи, подобны друг другу, даже духовно родственны. Но насколько же более цивилизованным, гуманным, «европейским» оказывается лидер азиатского государства (Турецкой Республики) по сравнению с главным идолом революционной России! В процессе лаицизации Республики Кемалю Ататюрку тоже приходилось идти на жесткие меры, отнюдь не популярные в глазах остального мусульманского мира (ликвидация халифата, запрет деятельности суфийских таррикатов и многое другое), но даже в самые суровые времена ему и в голову не могло придти то, что Ленин считал вполне нормальным и «человечным», а именно «убивать» (физически уничтожать, расстреливать!) как можно больше православных священников. Имамов-настоятелей мечетей Ататюрк не расстреливал и в Соловки не ссылал, даже халифа не убил, а только изгнал из Турции, мечети в стране не разрушал, не взрывал и не превращал в свинарники, а строил (позволял строить), в том числе и в Анкаре, куда он перенес столицу государства. Религиозная политика - это только одно направление деятельности данных «национальных лидеров». Можно вспомнить и многое другое, например, расстрел - без суда и следствия - царской семьи, уничтожение офицерского корпуса «белой» армии после взятия большевиками Крыма, кровавые преступления руководимой поляком Дзержинским ЧК, «военный коммунизм» в России, искусственно организованный голод в Поволжье, - многое, подобного чему в Турции не было. Вспомнить, чтобы спросить: так кто же из двух, отчасти подобных друг другу национальных лидеров - Ленин или Ататюрк - был большим варваром, большим преступником, большим «азиатом» (если позволительно использовать это слово для негативной аксеологической характеристики), большим «европейцем» (если опять же условно придать этому понятию позитивное значение, связать его не с географией, а с уровнем цивилизации и прогресса)? Ответ окажется однозначным. 


\section{Европейский и азиатский «культ личности»}

Сложность заключается еще и в том, что в массовом отношении к «своему» национальному лидеру со стороны народа вовсе не прослеживается (во всяком случае далеко не всегда прослеживается) предполагаемый ab ovo, казалось бы, предопределенный различием господствующих религий - ислама (а говоря об Азии, я имею в виду прежде всего мусульманский азиатский мир) и европейского христианства во всех его конфессиональных ответвлениях, а соответственно предопределенный и характером исторически сложившегося национального менталитета народов Азии и народов Европы контраст между безусловным и беспрекословным подчинением своему лидеру (хану, шаху, султану, королю, эмиру, айатолле, президенту светского государства), обожанием такого лидера (в азиатских странах) и сохранением гражданского достоинства, определенной дистанции между собой и национальным вождем, формированием такого поля, в котором возможны и критика, и оппозиция, и выражение сомнений в непогрешимости национального лидера (в странах европейской политической культуры). Конечно, отчасти этот контраст еще прослеживается, и в Европе рубежа XX-XXI веков трудно представить себе нечто вроде политического феномена Туркменбаши (бывшего Первого Секретаря Коммунистической партии Туркменистана). В то время как из европейских мавзолеев выносятся последние останки бывших диктаторов (Ленин в мавзолее на Красной площади еще лежит, но хрустальная пирамида в Тиране, в которой покоилась мумия Энвера Ходжи, превращена в столичную дискотеку), в Азии создаются сверкающие мрамором и золотом, переливами мозаик и хрусталя, окруженные садами и фонтанами, роскошные гробницы современным политическим лидерам - вельможам и богдыханам уже отнюдь не феодальных империй, а молодых азиатских государств: и семейная гробница Туркменбаши в Кипчаке, и затмившая своей роскошью все прежние чудеса света мечеть-гробница Шейха Заида в Абу-Даби - не единственные тому примеры.

Однако, и с этой точки зрения, если вникнуть в ситуацию глубже, поднять разные пласты европейской истории, можно с изумлением 
обнаружить, что не Азия, а Европа окажется родиной «культа личности», принесшего колоссальные бедствия многим народам, надолго и глубоко травмировавшего их национальную психику. «Великого» Сталина обожала Россия, «великого» Гитлера - Германия и Австрия, «великого» Франко - Испания, «великого» Тито - значительная часть Югославии, а это были отнюдь не азиатские страны. Именно к европейским народам обращала русская поэтесса Марина Цветаева свои горькие стихи:

А Бог с вами!

Ходите овцами!

Ходите стадами, стаями

Без меты, без мысли собственной

Вслед Гитлеру или Сталину

Являйте из тел распластанных

Звезду или свасты крюки» ${ }^{4}$.

Это они, европейцы - не азиаты (хотя надо отдать некоторым азиатским народам должное, они быстро этому научились) «ходили овцами», «ходили стадами и стаями» под властью своих преступных лидеров и своими распластанными (не только физически, но и духовно!) телами формировали красные звезды или крючки свастик на физкультурных парадах и демонстрациях. Потомки этих «овечьих стад» до сих пор выходят на улицы с портретами Сталина 7 ноября и 9 мая или отмечают день рождения Гитлера 20 апреля. Европейцы - не азиаты!

${ }^{4}$ Цитируется на основе публикации этого стихотворения в книге: Поликовская, 2009, с. 186. 


\section{Военная (воинствующая) составляющая в образе азиатского и европейского лидера}

Существует еще один важный параметр, определяющий категорию «национального лидера» и особенности европейского и азиатского восприятия этой категории. Речь идет о воинственности такого лидера как в отвлеченном, моральном, так и в совершенно конкретном, профессиональном измерении. Опять же при первом приближении к этой проблеме, на первый, поверхностный взгляд кажется, что азиатский политический лидер - это прежде всего воин, некий условный и бессмертный Чингизхан, захватчик чужих земель, победитель (титул «победоносного» и «непобедимого» включали в себя тугры многих султанов Османской империи ${ }^{5}$ ), в то время как в рамках европейской политической культуры национальным лидером может стать философ, ученый, поэт, рабочий судостроительной верфи, предприниматель, кадровый партийный работник или государственный служащий (Ельцин), человек, никогда не седлавший боевого коня и не державший в своих руках ни меч, ни лук, ни забрало, ни автомат Калашникова - ни в прямом, ни в переносном смысле этого слова.

Такое представление отчасти соответствует действительности. Вся исходная история ислама, возникшего в духовном эпицентре Азиатского континента - на Аравийском полуострове, - это история постепенно расширения «земли Ислама» - «дар аль Ислам», раздвижения - на восток и на запад границ Халифата, победоносных вы-

5 Эта традиция сохранялась на протяжении многих веков. Так, тугра султана Сулеймана Великолепного XVI века заключала в себе формулу «Сулейман - шах, сын Селима шаха, всегда побеждающий»; тугра султана Мехмеда VI начала XX века содержала текст «Мехмед Вахидеддин, сын Абдулмеджида, всегда побеждающий» (Kołodziejczyk, 2013, c. 54); и хотя никакими победами правление Мехмеда VI ознаменовано не было и окончилось в ноябре 1922 года его бесславным бегством из страны (Steinbach, 2000, с. 27), до самого конца существования Османской империи чрезвычайно важным моментом в ее идеологии и политической риторике оставалась характеристика главы государства («лидера нации») как отважного воина и победителя. Даже с исчезновением империи ментальность ее мусульманского населения не сразу изменилась, и первый Президент Турецкой Республики Кемаль Ататюрк в глазах народа выступал в ореоле одержанных им военных побед над врагами Турции. 
ступлений арабской конницы, дошедшей, как известно, не только до Испании, но и до Франции (едва остановленной в битве под Пуатье). Только в период правления первых четырех «справедливых» халифов (632-661 годы) исламское государство (арабский Халифат) расширило свои владения, которые уже включали Египет, значительную часть Северной Африки, Сирию, Ирак, Персию; мусульманское войско под предводительством своих отважных руководителей, доходило до границ Индии, Византийской империи, Кавказа, Туркестана. Последующие завоевания возглавили халифы династии Омайядов, которая правила Халифатом почти век (в 661-750 годах). Арабская конница двигалась на Запад по северному побережью Африки, втягивая в свои ряды племена берберов, и дошла до Атлантического океана. В 711 году объединенное арабо-берберское войско высадилось в Испании и, разбив визиготов, в течение семи лет заняло весь Пиренейский полуостров. Под угрозой оказалась оказалась Франция. Дальнейшее продвижение арабов вглубь Европы остановил только Карл Молот, одержав над ними победы в битвах под Тур и Пуатье в 732 году. В те же самые годы арабы вели успешное наступление на восточном фронте. Потерпев сокрушительные поражения в битвах под Кадесией (в 637 году) и Нихавендом (в 642 году) пала персидская империя Сасанидов. Арабы завоевали Афганистан, в 711 году вторглись в Синд и далее в Пенджаб, к XI веку им уже принадлежала значительная часть северной Индии.

Достоинства лидеров мусульманского государства - от его основателя Пророка Мухаммада и первых четырех праведных халифов до глав позднейших династий - измеряются в сознании мусульман («азиатов») прежде всего их военными успехами, и были эти лидеры не только организаторами, но и непосредственными участниками военных походов и сражений. Это прочно осталось в исторической памяти мусульманских (азиатских) народов и наложило свой отпечаток на формирование образа (категории) лидера в их понимании. Прекрасно, можно сказать, «пришелся ко двору» мусульманской Азии, вписался в контуры азиатских представлений о лидере Чингизхан, совершившийся свой победоносный поход с Востока на Запад, и это несмотря на то, что ни сам Чингизхан, ни его сыновья еще не были мусульманами, а жертвами их наступательных походов 
как раз оказались многие мусульманские народы и очаги разрушенной монголами исламской цивилизации (в Средней Азии, Волжской Булгарии и в других регионах). Легенда о доблестном и непобедимом Чингизхане сыграла огромную роль в формировании национального сознания и национального достоинства не только тех народов Центральной Азии (прежде всего монголов и бурят), которые идентифицируют себя с ним по национальности, считают себя потомками его рода, но и народов, к этногенезу которых завоевания Чингизхана имеют лишь частичное, косвенное отношение, например, поволжских и крымских татар. И что уж говорить о сибирских, поволжских или крымских татарах, если даже среди польско-литовских татар, этническая группа которых формировалась в Европе на землях бывшего Великого Княжества Литовского, живет устойчивое представление о их близости к Чингизхану и его наследникам - ханам Золотой Орды, и на этой (в высшей степени воинственной) основе формируется представление о национальном лидере. Селим Хазбиевич, чья поэзия имеет огромное влияние на самосознание польско-литовских татар, постоянно обращается к мотивам и образцам военной доблести как к первооснове национального героизма:

Jeszcze dziś słychać jeźdźców wspaniałych,

Słychać rżenie koni oszalałych,

Rwie z kopyt chorągiew tatarska,

I jasno od szabel z pochew dobywanych ${ }^{6}$.

Свою личную причастность к славе предков (вымышленных предков, чрезвычайно важных, однако, для укрепления собственного достоинства современного мусульманина, в реальности ничего общего с военной и захватнической деятельностью не имеющего) поэт выражает словами:

${ }^{6}$ Chazbijewicz, 1997, с. 28. Подстрочный перевод: «И сегодня еще слышно, как мчатся по степи великолепные наездники, как ржут их обезумевшие кони, взлетает над ними татарское знамя, и ослепительный свет исходит от сабель, вырванных из чехлов». 
Ojcze mój duchowy i przodku - Dżyngiz Chanie będący oczekiwaną mistyką Azji

Wodzu Duchowy idei Wielkiego Turanu

ojczyzny wszystkich ludów tureckich

żelazna orda mongolska konnica step

błysk szabel nieprzeliczone ilości

wojowników świst arkanów tętent kurz stepu

chłodna poranna rosa modlitwy

Ojcze mój duchowy Dżingiz Chanie

oto ja Twój potomek w środku Europy...?

Подобная интонация звучит и в поэзии литовского татарина Адаса Якубаускаса. Он пишет:

To ja - potomek krymskich chanów

I stepowy jeździec srogi.

Głos doniosły tych ułanów,

Co na Litwie bili wrogów.

Jestem synem murzów walecznych

Z wolną duszą polskiej szlachty,

I prawnukiem jeźdźców dawnych,

Co pod Grunwaldem pełnili wartę ${ }^{8}$.

При ближайшем рассмотрении, однако, скоро оказывается, что «военная составляющая» развита не только в мусульманских (азиатских) представлениях о национальном лидере и характерна для

7 Chazbijewicz, 1990, с. [11]. Подстрочный перевод: «О, Чингизхан, мой духовный отец и предок, Ты - мистика Азии, ожидаемая извечно, Ты - духовный вождь идеи великого Турана, родины всех тюркских народов, железная монгольская орда, степная кавалерия, блеск сабель неисчислимого множества воинов, свист арканов, топот, степная пыль, холодная утренняя роса молитвы, Отец мой духовный Чингизхан, вот я - Твой потомок в середине Европы...».

8 Цитировано на основе публикации: Pavlenko, 2016, с. 265. Подстрочный перевод: «Я - потомок крымских ханов и бесстрашный степной воин. Я - голос тех уланов, которые били врагов Литвы. Я - сын тех отважно сражавшихся татарских мурз, в которых жила свободная душа польской шляхты, и я - правнук тех давних кавалеристов, что несли свою вахту в битве под Грюнвальдом». 
биографий государственных деятелей этого мира, претендующих на роль таких лидеров, начиная от самого Пророка Мухаммада. В исторической памяти европейских, приобщенных к христианской цивилизации народов образ героя-воина (сакрального «Святого Георгия-Победоносца» и не всегда приобщенных к лику святых полководцев старых и новых времен) имеет огромное значение в формировании представлений о национальном герое и вожде, и эта память простирается не только на времена первых польских королей из династии Пястов - Мешко Первого, Болеслава Храброго, Великих литовских князей Гедиминаса и Витаутаса, легендарных «защитников земли русской» Александра Невского и Дмитрия Донского (в действительности, далеко не всегда достойно исполнявших эту роль «защитников) и прочие страницы истории далекого Средневековья, но также и на великих мира сего Нового и Новейшего времени - Наполеона, которого обожает вся Франция, Юзефа Пилсудского, которого обожает вся Польша.

Европейский лидер не реже, чем азиатский выступает в воинственной роли не только защитника своего Отечества, вынужденного сражаться за его свободу, но и завоевателя, чья слава (нередко весьма сомнительная) зиждется на захватах, на присоединении к своему Отечеству новых земель. Не забудем, что обе самые страшные войны в истории человечества - Первая и Вторая мировые войны - были развязаны не азиатскими, а именно европейскими политическими лидерами (азиатские народы и страны в них тоже участвовали и в роли агрессоров, и в роли жертв агрессии, но «поджигателями» этих войн не были). Не надо даже обращаться к далекому прошлому, достаточно посмотреть на современную Россию, чтобы убедиться в том, что в европейской Москве находится сегодня самый опасный для всего мира источник военной агрессии, и не только потенциальной, но и реализованной на наших глазах (по отношению к Украине, к Грузии, к Молдавии, к так называемой «сирийской оппозиции», то есть к значительной части сирийского народа, не желающего мириться с режимом Асада). Пока маленький азиатский лидер еще только грозит миру из Пхеньяна атомным оружием (в последнее время, впрочем, нерешительно), Россия уже погубила на своих атомных полигонах многих собственных граждан, скончавшихся от лучевой 
болезни, и «очистила» немалые территории (например, остров Новая Земля) от их исконных обитателей - туземных народов - для опытов с атомным оружием. При этом действующий лидер современной России, в очередной раз избранный ее Президентом в 2018 году, безусловно пользующийся массовой поддержкой ее населения (подавляющего большинства), несущий всю полноту ответственности за агрессивные действия российского государства в XXI веке, ничего общего с азиатскими стереотипами национальных лидеров не имеет, и по всем данным своей внешности, известной родословной, языку, месту рождения и воспитания (Ленинград), демонстрируемой им на православных праздниках религиозности является отнюдь не азиатом, не мусульманином, а русским человеком, европейцем.

\section{Религиозный деятель / представитель духовенства в роли политического лидера: азиатская и европейская перспективы}

В Азии (здесь я имею в виду прежде всего мусульманскую Азию, хотя и на Тибет этот вывод распространяется) современным политическим лидером чаще может стать религиозный деятель (далай-лама; мусульманин салафитской секты, объявивший себя новым халифом - заместителем Пророка; ваххабит, начиная от самого Ваххаба, по имени которого называется эта секта и который был настоящим духовным лидером формирующейся Саудовской Аравии ${ }^{9}$; суфийский

9 Мухаммад Ибн-Абд-аль-Ваххаб (1703-1791) родился в недждийском городе Уйане в небогатой, но по-своему знатной семье улема (ученого богослова) рода Ааль-аш-Шейх из арабского племени банутамим. Как сына бедного пастуха и образованного богослова представляет Мухаммада Ибн-Абд-аль-Ваххаба А.Е. Крымский, который, можно сказать, впервые ввел это имя в поле российской историографии (Крымский, 1912). Как справедливо отмечали почти все исследователи духовного наследия Мухаммада Ибн-Абд-аль-Ваххаба, формально он не создал никакого нового учения, не сформулировал новых догматов веры, но «лишь стремился восстановить среди арабов религию ислама в ее первоначальной коранической чистоте» (Шумов, Андреев, 2003, с. 124). Однако, оказалось, что именно под знаменем „чистого” ислама открываются широкие возможности для политизации и радикализации религиозного учения. В своих проповедях Мухаммад Ибн-Абд-аль-Ваххаб стремился к последова- 
шейх, глава воинствующего тарриката (например, связанный с воинственным таррикатом Накшбандия имам Шамиль, возглавивший в XIX веке национально-освободительную борьбу горцев Кавказа); муфтий; айатолла, статус которого в Конституции современной Исламской Республики Иран четко определен следующим образом:

...Пока продолжается тайное укрытие двенадцатого имама, правительство Исламской Республики Иран и руководство общиной верных складывается из справедливых, честных, послушных Богу и обладающих знаниями

тельному утверждению принципа единобожия („таухид”), согласно которому Аллах - единственный, абсолютный источник божественной силы, правящей миром. Этот последовательный, категоричный, воинственный монотеизм был важнейшей основой учения, которое могло сплотить всех арабов, положить конец племенной раздробленности. Проповедь аскетизма, суровой простоты нравов, давшая повод западным авторам назвать ваххабитов «пуританами пустыни», была, разумеется, не самоцелью, а средством завоевать симпатии социальных низов и направить народный гнев против правителей Османской империи, погрязших в роскоши и разврате. Главным в проповедях Мухаммада Ибн-Абд-аль-Ваххаба было укрепление „железного”, нерушимого единства рядов праведных мусульман (на жесткой основе монотеистического вероучения) и фактор джихада - священной войны, в которую должны были быть вовлечены праведные мусульмане. В реальные бои и сражения Мухаммад ИбнАбд-аль-Ваххаб, однако, не сам повел своих соотечественников. Уже в период его деятельности сложилось, можно сказать, четкое разделение функций между духовными лидерами, проповедниками, целыми общинами ваххабитов, занимавшимися по сути лишь теорией джихада, вооруженными только словом, с одной стороны, и политическим руководством массового движения, государственными деятелями (эмирами, племенными вождями-шейхами, будущей королевской династией), военными структурами, с другой стороны. Проповеди Мухаммада Ибн-Абд-аль-Ваххаба и его призывы к единству арабского мира были услышаны людьми, способными носить и применять оружие. Последователем Ваххаба стал отправились в Дерейи - эмир Мухаммед ибн Сауд (из рода Аль-Саудов), Он назвал себя «мечом» своего учителя, и как пишет А.Е. Крымский, «распространял его учение вооруженной рукой» и стал основоположником Саудовской династии, ставшей во главе освободившейся от политической зависимости Аравии. Духовные проповеди исламского богослова и политические цели вооруженной борьбы слились в процессе создания этого государства в единое целое. Ваххабизм в руках Мухаммеда ибн Сауда и его преемников стал мощным оружием объединения аравийских племен вокруг Саудовской династии. 
(знающих исламское право) ученых, признанных

большинством населения за предводителей (айатолла) ${ }^{10}$.

Первым в качестве такого предводителя (временного заместителя «укрытого имама») был признан айатолла Хомейни, который максимально использовал этот сакральный ореол «духовного лица» в своей роли политического лидера и предводителя революции в Иране ${ }^{11}$.

Возможно ли, что европейский священник (католический ксендз, лютеранский пастырь, православный поп хотя бы в высшем духовном звании патриарха) в Европе XX-XXI веков окажется в роли национального политического лидера? Почти невозможно. Видимо, запас той политической активности, которым христианская церковь обладала в Средние века и даже на заре Нового времени, исчерпан; времена Мартина Лютера и Томаса Мюнцера прошли, и даже в исключительных случаях массовые проявления особенного почтения, особенного уважения, доверия, любви, какими пользовался, например, «польский папа» Ян Иоанн Павел Второй (да и до него, и после него пользовались некоторые хранители апостольского престола в Ватикане), не способны превратить служителя церкви в политического лидера - ни в масштабе одной страны, ни в широком поле данной конфессии. Возможно, последний раз такую роль взял на себя глава автокефальной православной церкви на Кипре и «этнарх» (предводитель) местной греческой общины, архиепископ Макариос III (в миру - Михаил Христодулос Мускос, 1913-1977), ставший в 1959 году Президентом независимой от британской короны Республики Кипр и соединивший в своих руках церковную и государственную власть, но как известно, ничем хорошим это не кончилось: преследования турецкого (мусульманского) меньшинства, по-

10 В переводе на польский язык эта статья Конституции Ирана гласит: «dopóki trwa nieobecność 12-go Imama rząd Islamskiej Republiki Iran i kierownictwo wspólnotą wiernych składa się ze sprawiedliwych, prawowitych, posłusznych Bogu i posiadających wiedzę (znających islamskie prawo) uczonych, uznanych przez większość ludności za przywódców (ajatollah)» См.: Scarbel, 2004, c. 49-51.

11 Подробно его деятельность и взгляды рассмотрены в книге: Ramazani, 1986. “Культ личности» Хомейни при его жизни и после смерти нашел отражение во множестве плакатов, рисунков и прочих пропагандистских клише, которыми переполнен современный художественный рынок Ирана (см.: Kleiber, 2009). 
ощряемые архиепископом и вылившиеся в кровавые столкновения 1963-1964 годов, раскололи Кипр как единое государство, привели к территориальному размежеванию турецкого (мусульманского) и греческого (православного) населения, а в конечном итоге к формированию Турецкой Республики Северный Кипр.

\section{Этническая и супер-этническая (интернациональная) основы феномена лидера (вождя, «отца нации») в европейских и азиатских культурах}

Другая особенность категории «национальный лидер» и ее восприятия в европейском и азиатском (мусульманском) сознании, в самом отношении к такому лидеру, независимо от меры его популярности, заключается в том, что «мусульмане» («азиаты»), даже безусловно признавая авторитет и «правоту» своего вождя, сохраняют в своем эмоциональном отношении к нему своего рода достойное спокойствие. До таких массовых истерик, демонстрирующих обожание (вплоть до нескончаемых оваций, которыми встречалось каждое слово Сталина, и совсем позорного для европейской культуры движения немецких женщин, мечтавших иметь ребенка от фюрера и в бурных демонстрациях и криках публично «озвучивавших» это желание), дело доходит редко, да и само явление «культ личности» оказывается не азиатским, а европейским изобретением.

Возможности для критики действующего лидера (внутрипартийной и внутригосударственной), для выражения сомнений в правильности того или иного принятого им решения на мусульманском Востоке шире, чем в европейских странах, переживших кошмары фашистской, коммунистической диктатуры и даже облегченные «авторитарные» режимы. Разумеется, любая тирания, на Востоке и на Западе, ограничивает свободу слова, свободу критики, возможность выражения недоверия к политическому лидеру, пришедшему к власти, но до таких крайних форм жестокого преследования за неосторожно сказанное слово, как это имело место в Европе и при Сталине, и при Гитлере, и даже при более слабых диктаторах такого типа, как Брежнев или румынский Чаушеску, на мусульманском Востоке, 
в Азии, дело, как правило, не доходит. Там тоже существуют и тюрьмы, и политические узники, подвергаемые пыткам, там даже совершаются публичные казни, которые в европейских странах законодательно запрещены, но там убивают не за веселую шутку бессмертного Насреддина, не за лукавую притчу странствующего дервиша, а за реальное сопротивление установившемуся режиму, за жизнь не по его правилам.

Различия касаются и самого определения-прилагательного «национальный» к слову «лидер». В европейской интерпретации оно чаще привязано к этнической первооснове нации, хотя современная политическая корректность обязывает многих реальных европейских лидеров (прежде всего глав государств) в своей риторике время от времени или постоянно напоминать о том, что они представляют интересы не только своего этноса, а всех граждан, «народов» и «меньшинств», здесь проживающих. Но риторика мало меняет суть дела, и никто не сомневается в том, что, к примеру, Юзеф Пилсудский был (есть) прежде всего национальным героем / лидером поляков, Витаутас Ландсбергис - литовцев, Дудаев и Масхадов - национальными героями / лидерами чеченцев (даже с братьями-ингушами ни они себя, ни ингуши их не идентифицировали), Ельцин и, к сожалению, также Путин - русскими национальными героями / лидерами, хотя они предпочитают называть своих соотечественников не "русскими», а «россиянами». Этно-национальная основа в мировоззрении, в деятельности европейского политического лидера, в его восприятии современниками и потомками, соотечественниками и иностранцами остается доминирующей. Исключения, впрочем, и в Европе бывали, например, когда Ленин, Троцкий, Дзержинский, Сталин и другие большевики разных национальностей пытались строить на одной шестой части земной суши свой «интернационал», но продолжалось это недолго: уже Сталин от интернациональной риторики фактически отказался в пользу риторики, утверждающей приоритетное положение русского народа («Союз нерушимый республик свободных сплотила навеки великая Русь», - утверждал принятый в конце Второй мировой войны новый гимн Советского Союза, заменивший прежний Интернационал). 
Мусульманский Восток, как и вся Азия, тоже глубоко затронуты процессами «нацио-строительства» (“Nation-Building”), и этнический фактор все более активно выступает в самосознании азиатских народов, а соответственно в риторике и политике их политических («национальных») лидеров. Наиболее яркий пример в этом направлении показал Кемаль Ататюрк, который решительно предпочел национальную идею (Türkçük) всем разновидностям пантюркизма (Türkçülük), панисламизма, османизма и иным идеологиям, не опирающимся на этническое самосознание турок. Но Турция - это еще не вся Азия, а в глубинах сознания ее мусульманских народов очень сильным остается представление о единой $\boldsymbol{y м \boldsymbol { ⿲ ㇒ 丨 丶 } ㇒}$ (общине всех мусульман независимо от их национальных различий). В арабском мире, разделенном на множество государств, очень сильной является общеарабская солидарность, имеющая и свои позитивные, и свои крайне негативные проявления (например, в войнах против государства Израиль). В таких условиях любой «национальный лидер» в этом мире не может быть только «национальным» в узком, этническом или государственном измерении. И удостоенный в 1994 году Нобелевской премии мира Ясир Арафат, верховный главнокомандующий вооруженными силами палестинского движения сопротивления, провозглашенный в 1989 году Президентом Палестинского государства, воспринимается арабами (при его жизни и после смерти) как защитник интересов не только палестинцев, но всего арабского мусульманского мира; и нынешний король Саудовской Аравии действует, как им кажется, в интересах не только своей династии и не только своей процветающей страны, но всех арабов, а возможно и всех мусульман мира. Великого крымскотатарского просветителя Исмаила Бея Гаспринского (1851-1914) современники (мусульмане) называли «отцом нации», причем так его называли не только в Крыму, а на Урале и на берегах Волги, в Средней Азии, в Османской империи, даже в далеком Бомбее, где по его «новому методу» («усул аль-джадид») были созданы мусульманские школы, самые прогрессивные для начала XX века; так его называли литовские татары, о которых он с большим уважением писал на страницах своей газеты 
«Терджиман» и своем сочинении Русское мусульманство ${ }^{12}$. Людям, мыслящим современными национальными, прежде всего европейскими категориями, нелегко понять, отцом какой же именно нации был Исмаил Гаспринский. Вероятно, не только крымских татар, а где проходят и где кончаются границы того мира, нравственные основы жизни которого Гаспринский определил в своей знаменитой триаде «Dilde, fikirde, işte birlik / Единство в языке, мыслях (вере) и делах», - этого не начертано на современных картах Азии и Европы, эти границы можно сузить до обозначения группы тюркских, исповедующих ислам народов Российской империи и расширить почти до бесконечности, включив в них весь тюркоязычный и весь мусульманский мир четырех континентов.

\section{Крымские примеры: сходство и различия идеальных моделей «национального лидера» на разных исторических этапах}

Я выбрала несколько имен признанных лидеров крымскотатарского национального движения и сам полуостров Крым для того, чтобы особенно наглядно представить и подчеркнуть, какое разное содержание вмещает в себя понятие «национальный лидер», как сложно переплетаются в нем явления, выработанные в русле, с одной стороны, европейской, с другой стороны, азиатской культуры, как много здесь противоречий и как интересно в этих противоречиях разобраться. Сам полуостров Крым в этом отношении оказывается интереснейшей пограничной зоной между Европой и Азией. Формально, географически он, конечно, находится в Европе, но долгие века господства ислама и развития мусульманской культуры на этой земле, прочные связи, постоянные контакты между Крымом и Турцией придавали ему восточный облик. Крым как бы постоянно смотрелся - через водный простор Черного моря - в свое турецкое зазеркалье, находил там собственное подобие, духовное родство, ценности, ему близкие. И было так еще до создания Османской империи, когда вся

\footnotetext{
12 Гаспринский, 1985, с. 86.
} 
архитектура татарского Крыма уже была под сильнейшим влиянием сельджукизма, и в годы расцвета этой империи, осуществлявшей над Крымским ханством свой политический протекторат, и после крушения Османской империи, когда уже республиканская Турция была местом концентрации крымскотатарской политической эмиграции в межвоенный и военный период, когда с Турцией крымские татары связывали все надежды на спасение, когда крымскотатарская диаспора в Турции, формируемая многими волнами вынужденного мохаджерства (эгзодуса татар из российского и советского Крыма) уже измерялась миллионами человек. В уникальном по своей благодати крымском климате перекрещивались мощные культурные импульсы, исходящие из европейской и азиатской цивилизаций.

Эта исключительная ситуация оказала свое влияние на формирование здесь национальных (политических) лидеров, на их характер, на диапазон их деятельности, на выдвижение ярких личностей, равных которым - во время их жизни - трудно найти где-либо еще.

Вернусь к тому же Исмаилу Гаспринскому, чье имя я уже упомянула (подробно излагать биографии ни его, ни его последователей не буду из-за доступности - в литературе и электронных сетях - множества фактов, на эти биографии накладывающихся; сконцентрирую внимание на самой сути феномена «национальный лидер»). Кем был - в профессиональном и социальном измерении - Исмаил Гаспринский, ставший первым в XX веке признанным лидером, «отцом народа»? Человеком из дворянской среды, получившим блестящее образование (и мусульманское, и европейское) в Бахчисарае, Воронеже, Москве, наконец, в парижской Сорбоне, причем образование в разных сферах, от военного и педагогического до филологического (в Париже он некоторое время работал литературным секретарем русского писателя Ивана Тургенева), прекрасно знавшим многие языки, классическую и современную литературу, в том числе русскую, французскую, турецкую, японскую. Человеком, объездившим пол-мира (его отрочество начиналось с попытки «бежать» из Российской империи в Стамбул, в отрочестве это не удалось, но за свою жизнь он не раз приезжал в Турцию и исколесил оба материка - от Испании до Индии). Учителем, отдавшим свои силы и годы жизни практическому обучению мусульманских детей и разработке 
нового прогрессивного метода школьного обучения. Название этого «нового метода» (usul-i ceded) определило наименование не только типа «новометодных» школ, но широкого общественного движения - джадидизма и его сторонников - джадидов. «Новый метод» позволял учащимся, сохраняя свою языковую и конфессиональную идентичность (никакой русификации!), значительно расширить круг знаний по сравнению с тем, что предлагали старые программы исламских школ-мектебе. Джадидизм стал широким движением, направленным на социальное, политическое, культурное обновление и реформирование всего образа жизни мусульман, на их приобщение к современному техническому и экономическому прогрессу. Исмаил Гаспринский был журналистом, публицистом, основателем и издателем первого в России общетюркского периодического издания «Терджиман / Переводчик», выходившего непрерывно с 1883 до 1918 года (после смерти Исмаила Гаспринского в 1914 году это издательское дело еще в течение четырех лет продолжали его сын и дочь; с советской властью они сотрудничать отказались). Гаспринский был человеком поистине универсального (подобно мастерам Возрождения) дарования - создателем своеобразного общетюркского эсперанто - «общего языка» (Lisan-i umumi), понятного практически всем народам тюркского мира; художником, усовершенствовавшим графическое оформление периодических изданий и начавшим новое дело их иллюстрирования рисунками; писателем - автором лирической прозы (Франиузские письма), утопических романов (в духе социалистических утопий). Он был политическим деятелем - участником (членом президиума, председателем) первых мусульманских съездов в царской России ${ }^{13}$. Он был человеком высокого гражданского муже-

13 Первый конгресс, который вошел в историю под именем Мусульманского собрания, состоялся в Нижнем Новгороде 15-28 августа 1905 года. Его первая резолюция требовала объединения (Ittifak) всех мусульман России, стремящихся к проведению реформ, отвечающих требованиям общественной модернизации. Конгресс положил начало организационному объединению российских мусульман. Они были разделены на 16 округов, каждый из которых выбирал свою ассамблею (меджлис - meclis). Центральная Ассамблея должна была собраться в Баку. Второй Конгресс, на котором председательствовал Гаспринский, собрался в Санкт-Петербурге 13-23 января 1906 года. На Кон- 
ства и в то же время определенной гражданской лояльности по отношению к тому обществу, в каком он жил, и к той власти, какая царила во всей Российской империи и в Таврической губернии. В своей вере он оставался «верным и верующим» мусульманином, не обнаруживая при этом ни радикального фанатизма, ни враждебной нетерпимости к людям иных вероисповеданий. Он не участвовал ни в каких войнах, не посылал своих детей и своих учеников ни на одну войну, и вряд ли обратился бы в душе к великому завоевателю половины мира со словами „Ојсze mój duchowy i przodku - Dżyngis Chanie...”. Он не участвовал в заговорах, не совершал террористических актов, даже не одобрял «младотатар», избравших в начале XX века путь революционной (и неизбежно братоубийственной) борьбы, что было причиной первого драматического разлада в крымскотатарском обществе и первого горького разочарования (учителя в своих учениках, учеников в своем учителе). При этом до конца жизни он пользовался величайшим авторитетом и общественным признанием (даже большевики не решились сразу выступить против этого народного кумира, - очернительскую кампанию против него они начали сравнительно поздно - на рубеже 1920-30-х годов, а как только повеял ветер горбачевской «перестройки», Исмаил Гаспринский оказался первым среди крымских татар, морально «реабилитированных» (первая юбилейная конференция, посвященная Гаспринскому - приуроченная к 140-летию со дня его рождения - прошла еще в советском Симферополе в марте 1991 года).

Следующее имя, которое мне хотелось бы назвать, перебирая звенья той исторической цепи, какая формировалась из судеб «национальных лидеров» крымскотатарского народа, - это имя Нумана Челеби Джихана. С Гаспринским его связывает прямая духовная преемственность. Нуман Челеби Джихан (1885-1918) вырос на «Терджимане» и сочинениях Гаспринского, впитал их высокий гуманный дух;

гресс съехались 100 делегатов - представителей татар, киргизов, народов Крыма и Кавказа. Конгресс принял решение о создании Союза мусульман России (Russiya Müsülmanlarinin Ittifaki). Третий Конгресс собрался вблизи Нижнего Новгорода 16-20 августа 1906 г. Он принял решение о преобразовании Союза мусульман (Иттифака) в политическую партию, программа которой базировалась на идеологии пантюркизма. 
юношей-студентом, обучавшимся в Стамбуле, он встречал приезжавшего в Турцию Гаспринского, слушал его лекции, считал для себя высокой честью само знакомство с ним. Так же, как Гаспринский, Нуман Челеби Джихан был человеком литературного труда, только не прозаиком, а поэтом, создателем стихотворения Я клянусь / Ант эткенмен, ставшего национальным гимном крымских татар. Но все же у Нумана Челеби Джихана была совершенно иная судьба, и по сути это была совершенно иная политическая модель национального лидера. Вместо характерной для Гаспринского лояльности и вынужденных поисков компромисса с властью (без таких компромиссов был бы обречен на исчезновение «Терджиман» - его любимое детище), Нуман Челеби Джихан обнаружил горячую бескомпромиссность, стал участвовать в работе подпольных кружков и нелегальных организаций, за что ему грозил арест, и в Стамбул не просто «уехал учиться», а фактически бежал, эмигрировал: вместе со своим другом Джафером Сейдаметом он открыл первую страницу в истории крымскотатарской политической эмиграции в Турции XX века. Вернувшись в Крым, он со всей страстью включился в борьбу за освобождение своего народа от российского имперского ига, и это была несомненно революционная - по целям и методам - борьба. Она сильно отличалась от программы «младотатар», искавших союза с российской социал-демократией, Нуман Челеби Джихан был свидетелем Октябрьского переворота 1917 года и бандитского разгула «красных» матросов в Крыму в начале 1918 года, и хорошо понимал, что ни с каким «социализмом», ни с какой российской социал-демократией, вырождавшейся в большевизм, крымскотатарскому народу не по пути. Он выступил в совершенно исключительной роли - Муфтия Таврического, главы мусульман Крыма и всех западных губерний России. До него Российская империя умело использовала ею же искусственно созданный институт муфтията (и в центральных областях «внутренней» России, и на «национальных окраинах») в целях укрепления собственной власти, контроля над мусульманскими общинами, назначая на должность муфтиев послушных власти чиновников. Нуман Челеби Джихан оказался первым муфтием, избранным мусульманами Крыма и сумевшим использовать свой духовный авторитет не для услужения царской власти, а для ее ниспровержения. В 1917 году он 
возглавил движение за создание «мусульманских комитетов» (мускомов), покрывших весь Крым своей широкой сетью, и провел Первый мусульманский съезд, ставший прологом общенационального съезда - Курултая, открывшегося в Бахчисарайском дворце в декабре 1917 года, ставшего национальным парламентом возрожденного народа, принявшего исторические решения о создании Демократический Республик Крым и ее Конституцию («Основной Закон»), защищавшую права и свободы всех граждан Крыма ${ }^{14}$. Он возглавил правительство этой Республики (так называемую Директорию), а в феврале 1918 года стал жертвой первой волны большевистского террора, обрушившейся на татарский Крым. 23 февраля в Севастополе он был даже не казнен, а буквально растерзан пьяной большевистской сволочью - духовной праматерью нынешних хозяев «русского Крыма».

Свидетелем этой трагедии был ближайший соратник Нумана Челеби Джихана Джафер Сейдамет, который уже после революции, в эмиграции, в своей книге Крым, изданной в Варшаве в 1930 году, так описывал эти события:

«... Российские большевики к концу 1917 года сумели захватить всю территорию бывшей империи, за исключением земель, оккупированных Германией, и немногочисленная, хотя и отважная армия Республики Крым оказалась разбитой превосходящими ее десятикратно силами красных. Крым вызвал на себя этот удар отчасти потому, что его Генеральный штаб протестовал против злодейств, совершаемых в Севастополе, где большевики вырезали всех русских и татарских офицеров, отчасти потому, что дал обязательства Украине, обещая сделать все возможное, чтобы помешать распространению большевизма и пресечь деятельность связанных с ним группировок на территории Украинского государства. И Крым сдержал свое слово, разоружив на вокзале в Бахчисарае большевиков, которые собирались двинуться отсюда на север [на Украину]. В отчаянной и безнадежной борьбе с врагом крымчане за дорогую цену отдавали свои жизни. Это началось еще с первых сражений под Александровском, где татарская кавалерия пришла на помощь погибающей Укра-

14 Национальная Конституция. Основной закон крымскотатарского народа (13/26 декабря 1917 г. [W:] Губогло, Червонная, 1992, с. 22-25. 
ине, и закончилось битвой под Алмой 13 января 1918 года, когда наступило поражение войска Республики Крым, как организованной государством силы, но не было сломлено мужество тех, кто выжил и не потерял веру в лучшее будущее. Укрываясь в горах небольшими подвижными отрядами, армия ждала подходящей минуты, чтобы выгнать из Крыма ненавистных оккупантов...» ${ }^{15}$.

Из этого свидетельства видно, что Республика Крым («татарский Крым») под руководством своих решительных лидеров (сам Джафер Сейдамет был главой Генерального штаба армии, министром иностранных дел и военным министром Республики Крым, предводителем войска в сражении под Алмой, автором стратегического плана партизанской войны в крымских горах) и прежде всего под руководством главы Директории, Муфтия Таврического Нумана Челеби Джихана, была способна оказывать военное сопротивление захватчикам и последовательно выполнять свой интернациональный долг перед другими народами, вступившими в борьбу с большевизмом.

В истории крымскотатарского народа было немало людей, достойных - безусловно или хотя бы частично - высокого морального звания «национального лидера» - и в эмиграции, в частности в действующей в Варшаве в межвоенный период организации «Прометей», и даже в советском Крыму (пока еще не целиком была истреблена «Национальная партия / Милли Фирка», пока даже в высших эшелонах советских власти, например, во главе ЦИК - Центрального Исполнительного Комитета Крымской АССР, оказывались личности, способные ставить интересы крымскотатарского народа выше собственной служебной карьеры и возражать самому Сталину, - такой личностью был Вали Ибрагимов, убитый в 1928 году по приказу Сталина, начавшего кампанию яростной борьбы с «вали-ибрагимовщиной»; пока не исчезли в застенках НКВД во время большого террора 1937 года лучшие представители крымскотатарской интеллигенции, воспитанные еще Исмаилом Гаспринским), и в годы войны, и в страшное время тотальной депортации, осуществленной 18 мая 1944 года, и в «спецпоселениях», в ссылке.

\footnotetext{
15 Sejdamet, 1930, c. 77.
} 
Не имея возможности перечислить назвать все эти имена в одной статье, я напоминаю о них, чтобы не сложилось впечатления, что у крымских татар был всего один или всего два-три «национальных лидера». История была гораздо богаче. Но еще одно имя в этой истории назвать необходимо. Это имя Мустафы Джемилева. Я хотела бы сравнить его жизненный путь с биографией Исмаила Гаспринского, чтобы более выпукло представить и оттенить разные модели, разные типы «национального лидера», формирующиеся в разных исторических условиях.

Более, чем 93 года, - почти век отделяет дату рождения Исмаила Гаспринского (8/20 марта 1851 года) от появления на свет 13 ноября 1943 года Мустафы Джемилева, и кажется, ничто не объединяет их. Разве что - пространство вечно прекрасного, неизменно прекрасного Крыма, который они, с нежностью и печалью, с гордостью и отчаянием, каждый по-своему, но оба с одинаково высоким чувством национального достоинства могли называть своей Родиной.

Все остальное было различным: социальные предпосылки будущей деятельности, воспитание, сложившиеся взгляды, понимание конечных целей национального пробуждения, народного просвещения, справедливого, разумного государственного «обустройства» и выбор методов национально-освободительной борьбы и правозащитной деятельности. И даже если, кроме этих явных различий, было в их деятельности, характерах, духовных устоях личности и убеждениях глубинное, внутреннее сходство, оно неизбежно должно было скрыться под наслоениями времени, стать невидимым, непостижимым в нашем восприятии, настолько лежащее между биографиями этих людей столетие изменило всю атмосферу, обстановку, образ жизни и образ мыслей разных поколений, историческое поле, потенциал, риторику национальных движений прошлой, далекой эпохи и нашего, нового времени.

В младенчестве и раннем детстве, когда взгляд ребенка обретает осмысленность и впитывает окружающие его впечатления на всю дальнейшую жизнь, перед глазами маленького Исмаила была близлежащая к Гаспре татарская деревня Аджикой, утопающая в садах и виноградниках, стройная мечеть, большой красивый двухэтажный особняк с террасой, принадлежавший его отцу, образованному 
мурзе (дворянину), вскоре после рождения сына получившему чин поручика и должность переводчика у графа М.С. Воронцова. В ушах мальчика звучала и русская, и французская, и чистая крымскотатарская речь, и арабские речитативы - просодии Корана, который дети в мектебе заучивали наизусть.

Мустафе едва исполнилось полгода, когда на крымских татар обрушилась трагедия 18 мая 1944 года - трагедия тотальной насильственной депортации. Его народ вывозили из Крыма - студебекерами, эшелонами-теплушками с вагонами для скота, в которых запертые люди задыхались от жажды, страдали от голода, и звучали в его ушах плач детей и женщин, стоны умирающих, грубые окрики и брань сопровождавших эшелоны надсмотрщиков, да может быть, тихие молитвы матери. И земля, которую он впервые увидел и по которой научился ходить, была рабочей зоной крымскотатарских «спецпоселений»пустынной, безводной Андижанской области - места уготовленной им «вечной ссылки».

Когда Исмаилу Гаспринскому исполнился 21 год, он уже завершил образование в Московском военном и Воронежском училищах, в мусульманском медресе Зинджирли и смог отправиться в Турцию, а оттуда через Вену и Мюнхен в Париж, где ему предстояло учиться в знаменитой Сорбоне и провести многие прекрасные часы общения с русским писателем И.С. Тургеневым, жившим тогда в Париже. Когда Мустафе Джемилеву шел 22-й год, он был исключен из Ташкентского ирригационно-сельскохозяйственного института по политическому обвинению в том, что придерживается «антисоветских взглядов» и «извращенно трактует мудрое решение партии и правительства» о выселении из Крыма крымских татар, а спустя несколько месяцев, в мае 1966 года, его впервые арестовали (тогда по обвинению в отказе от службы в Советской Армии), и это звено было первым в той невыносимо длинной и невыносимо тяжелой цепи испытаний, многократных арестов, судебных процессов, тюремных заключений, лагерных сроков, в которых он провел в общей сложности восемнадцать лет.

Когда в апреле 1883 года, после многих стараний, отчаянных усилий, материальных затрат и сложной дипломатической борьбы с «компетентными органами» имперской власти, - борьбы, тре- 
бовавшей и мужества, и смирения, - вышел первый номер газеты “Терджиман”, его редактору и издателю Исмаилу Гаспринскому было 32 года, и слава, и признание, и восхищение современников, и почтение учеников, и уже просматривающаяся впереди благодарность потомков пришли к нему и поднимались потом все более сильными волнами.

В 1976 году, когда Мустафе Джемилеву исполнилось 32 года, в Омской следственной тюрьме, куда его перевели из лагеря строгого режима за три дня до окончания срока его заключения в этом лагере, по разработанному в КГБ сценарию над ним начался самый издевательский и жестокий процесс, и жизнь его тогда висела на волоске. В знак протеста он объявил «сухую» (без воды), смертельную голодовку, а общая его голодовка (с принудительным кормлением через зонд) продолжалась 303 дня, и тогда, можно сказать, весь мир встал на его защиту. Широкая кампания во имя спасения его жизни и за его освобождение развернулась за рубежами СССР. И слава тоже пришла к нему, очень нелегкая слава. Он бросил вызов «империи зла», выдвинув последовательную программу сокрушения этой империи бескровным путем, конституционными, демократическими средствами. Семь раз судимый тоталитарным режимом, он превращал каждый судебный процесс в гражданское единоборство с этим режимом и восхищал потрясенный мир своим беспримерным мужеством, душевной чистотой и твердостью, силой, блеском своего интеллекта и широтой эрудиции, обескураживая целые синклиты советских судей, прокуроров, следователей и обслуживающих карательную систему пропагандистов. В его защиту выступали президенты великих держав, лауреаты Нобелевских премий и безымянные демонстранты в столицах европейских, азиатских и американских стран, поднимавшие перед окнами советских посольств транспаранты с требованиями его освобождения.

Даже после смерти Сталина и освобождения крымских татар от статуса ссыльных и поднадзорных «спецпоселенцев» советская официальная, академическая наука не спешила вернуть им их духовное, культурное наследие, так же, как советское законодательство не спешило вернуть им их государственную автономию и их Родину Крым. 
Имя Гаспринского, уже вычеркнутое к этому времени из всех советских учебников и энциклопедий, и цитаты из его сочинений, в которых, как мы знаем, проповедовался отнюдь не радикальный, а толерантный, либеральный культурно-просветительский тюркизм, звучали тогда не в академических аудиториях, не с университетских кафедр, а на судебных процессах над крымскими татарами. И нужно было иметь немалое гражданское мужество, чтобы бросить это имя в лицо советскому суду так, как это сделал на омском процессе 1976 года Мустафа Джемилев, годами своего очередного заключения заплатив за право свободно и бесстрашно говорить о Гаспринском.

Я действительно долгое время, будучи на свободе, занимался исследованием творчества реформатора и просветителя Исмаила Гаспринского и действительно его портрет висит у меня [... дома], - говорил тогда Мустафа, отвечая на выдвинутое против него по доносу провокатора обвинение. - ... это было известно сотрудникам КГБ, которые ранее изымали у меня записи о Гаспринском. [...] меня спрашивали, кто такой Гаспринский, который воевал против России. И мне пришлось объяснить, что Гаспринский против России не воевал, потому что был штатским человеком, писателем и общественным деятелем, издавал газеты и журналы, открывал школы для мусульман Российской империи. Не совсем ясно, зачем понадобилось следствию помянуть Гаспринского, который умер в 1914 году и, стало быть, ничего порочащего советский строй не мог написать ${ }^{16}$.

И убийственная ирония, скрытая в этих словах Мустафы, и его издевательское презрение к чужой и неумной власти, которая, между прочим, отлично знала, зачем упоминать имя Гаспринского на процессе над Мустафой Джемилевым и как связать их круговой порукой общей идеологической «неблагонадежности»; и та спокойная обстоятельность, с какой говорил Мустафа о действительных трудах и заслугах Гаспринского, могут быть и заветом, и уроком для современных поколений крымских татар.

Ни единой тени не легло на имя Мустафы Джемилева за все эти страшные годы, ни малейшее подозрение в сотрудничестве с враж-

16 Российская Федерация против Мустафы Джемилева...., 1998, с. 39. 
дебным его народу режимом, в трусости, в доносительстве, в личном карьеризме не коснулись его. В полном соответствии с высокими традициями революционного романтизма он посвятил свою жизнь борьбе за счастье и освобождение своего народа. Он сумел совершить почти чудо, и возглавив сначала Центральную Инициативную Группу (ЦИГ, 1987), затем Организацию крымскотатарского национального движения (ОКНД, 1989) и, наконец, всенародно избранный Курултай - высший законодательный и представительный орган национального самоуправления, постоянно действующий национальный съезд и его исполнительный орган - Меджлис, он привел в действие сильнейшие механизмы политической организации и, сломав сопротивление агонизирующего режима (памятная Комиссия Верховного Совета СССР под председательством А.А. Громыко вплоть до 1988 года еще пыталась задержать возвращение на родину крымских татар ${ }^{17}$ ), добился реальной массовой репатриации и реабилитации своего многострадального народа. И народ ответил ему любовью, с упрямой устойчивой доминантой и взрывной пламенной силой, которой несопоставимы никакие высокие рейтинги политических лидеров, рвущихся к власти, и никакие «культы» старых и новых тиранов, этой властью обладающей. В лидерах можно разочароваться, тиранов можно свергнуть, - национальных героев никем заменить нельзя.

Сегодня Мустафа Джемилев изгнан из оккупированного Россией Крыма и продолжает свою деятельность в Киеве, в рядах крымсктатарской эмиграции в Украине. Все созданные при его участии с огромным трудом институты национального самоуправления и самообеспечения (Курултай, Меджлис, Фонд «Крым») сломаны, запрещены, разогнаны. Борьба продолжается.

${ }_{17}$ См.: Сообщение Государственной Комиссии, созданной для рассмотрения обращений граждан из числа крымских татар (9 июня 1988 г.) [W:] Губогло, Червонная, 1992, с. 54-55. 


\section{Выводы}

Таким образом, европейское и азиатское восприятие категории «национального лидера» по многим признакам оказывается как бы смешанным. Здесь трудно найти однозначные характеристики, жестко и категорично "разводящие» понятия «национального лидера» в европейской и азиатской интерпретации, противостоящие друг другу. Многие потоки массового политического сознания (и эмоционального подсознания) перетекают из европейского в азиатский и из азиатского в европейский мир, смешиваются друг с другом, дополняют друга друга, влияют на формирование политической модели лидера как в позитивную сторону, когда на первый план в образе и деятельности лидера выступают гуманное, интеллектуальное, рациональное, благородное начала (а это возможно и в христианской Европе, и в мусульманской Азии), так и в сторону негативную, когда лидером на некоторое время оказывается тиран, агрессор, шарлатан, параноик, просто бандит (а такое, к сожалению, возможно и в европейской, и в азиатской стране).

В условиях интенсивной глобализации это смешение (в построении умозрительных моделей идеального лидера, в реальной политической практике) происходит особенно часто, и все же исследование данной проблемы на научных основах современной культурной антропологии, социологии и этнопсихологии, позволяет выявить некоторые отличительные или во всяком случае наиболее характерные черты, присущие категории национального лидера, с одной стороны, в европейской, с другой стороны, в азиатской интерпретации.

ПРОФ. СВЕТЛАНА ЧЕРВОННАЯ

Университет Николая Коперника в Торуни swetlana@umk.pl 


\section{Литература}

Chazbijewicz, S. (1997). Rubai'jjat albo czterowiersze. Gdynia.

Chazbijewicz, S. (1990). Krym i Wilno. Gdańsk.

Kleiber, K. (2009). Irańskie wizerunki ajatollaha Chomeiniego z lat 1979-1988. Kraków.

Kołodziejczyk, D. (2013). Zaproszenie do osmanistyki. Typologia i charakterystyka źródeł muzułmańskich sasiadów dawnej Rzeczypospolitej: Imperium Osmańskiego i Chanatu Krymskiego. Warszawa.

Laurent, S. (2015). Kalifat terroru. Kulisy działania Państwa Islamskiego. Warszawa.

Pavlenko, S. (2016). Adas Jakubauskas - poeta litewsko-tatarski. Rocznik Tatarów Polskich, III (XVIII).

Ramazani, R.K. (1986). Revolutionary Iran. Challange and response in the Middle East. Baltimore-London.

Scarbel, A. (2004). Islam. Kraków.

Sejdamed, Dz. (1930). Krym. Warszawa.

Steinbach, U. (2000). Geschichte der Türkei. München.

Zdanowski, J. (2013). Historia społeczeństw muzułmańskiego Bliskiego Wschodu w XX wieku. Warszawa.

Гаспринский, И. (1985). Русское мусульманство / Gasprinski, I. Russian Islam. Oxford.

Губогло, М., Червонная, С. (1992). Крымскотатарское начиональное движение. Том II. Документы, материаль, хроника. Москва.

Крымский, А. (1912). Ваххабиты. Москва.

Поликовская, Л. (2009). Тайна гибели Марины Цветаевой. Москва.

Российская Федерация против Мустабы Джемилева. Омский проиесс. Апрель 1976 г. (1998). Киев.

Цыганок, А. (2016). Война в Сирии и ее последствия для Ближнего Востока, Какваза и Центральной Азии: русский взгляд. Москва.

Шумов, С., Андреев А, А. (составители). (2003). Ваххабиты XVIII-XX века. Москва. 